\section{Ter inleiding}

In ons land worden in ongeveer 75 ziekenhuisapotheken op kleine en grote schaal parenteralia bereid. Hoewel de produktievoorschriften voor de bereiding van parenteralia steeds uniformer worden, zijn de produktie-omstandigheden veelal verschillend.

Om een inzicht te krijgen in de kwalitatieve verschillen is in zeven ziekenhuisapotheken, tijdens de bereiding van natriumchloride infusievloeistof $0,9 \%$, een aantal in-process controles uitgevoerd.

In een serie van drie artikelen zullen naar aanleiding van deze in-process controles de volgende onderwerpen worden besproken.

I. Toetsing van de werkomstandigheden.

II. Toetsing van recipiënten.

III. Toetsing aan de hand van het produkt.

In tabel I zijn de verschillen in produktie-omstandigheden in de zeven ziekenhuisapotheken vermeld.

TABEL I. Bereidingsomstandigheden in zeven ziekenhuisapotheken

\begin{tabular}{|c|c|c|c|c|c|c|}
\hline \multirow{2}{*}{$\begin{array}{l}\text { Zieken- } \\
\text { huis }^{1}\end{array}$} & \multirow[t]{2}{*}{ Vullijn } & \multirow{2}{*}{$\begin{array}{l}\text { Lucht- } \\
\text { behandeling }\end{array}$} & \multirow{2}{*}{$\begin{array}{l}\text { Eénmalig } \\
\text { glaswerk }\end{array}$} & \multicolumn{2}{|c|}{ Laatste spoelwater } & \multirow{2}{*}{$\begin{array}{l}\text { Laatste filtratie } \\
\text { produkt }\end{array}$} \\
\hline & & & & rubbers & flessen & \\
\hline A & nee & geen & ja & demi $0,2 \mu \mathrm{m}$ & demi $0,2 \mu \mathrm{m}$ vers & $0,2 \mu \mathrm{m}$ \\
\hline B & nee & geen & $\mathrm{ja}$ & dest - & dest - recirculatie & $0,2 \mu \mathrm{m}$ \\
\hline $\mathrm{C}$ & nee & overdruk & ja & dest $0,2 \mu \mathrm{m}$ & recirculatie & $0,2 \mu \mathrm{m}$ \\
\hline $\mathrm{D}$ & nee & overdruk & ja & dest $0,2 \mu \mathrm{m}$ & dest $0,2 \mu \mathrm{m}$ vers & $0,2 \mu \mathrm{m}$ \\
\hline $\mathrm{E}$ & $\mathrm{ja}$ & overdruk & ja- & dest - & dest $0,2 \mu \mathrm{m}$ vers & $0,2 \mu \mathrm{m}$ \\
\hline $\mathbf{F}$ & $\mathrm{ja}$ & overdruk & nee & dest - & dest $0,45 \mu \mathrm{m}$ vers & $0,45 \mu \mathrm{m}$ \\
\hline G & $\mathrm{ja}$ & overdruk & ja & dest $0,2 \mu \mathrm{m}$ & dest $0,2 \mu \mathrm{m}$ vers & $0,2 \mu \mathrm{m}$ \\
\hline
\end{tabular}

${ }^{1}$ Ziekenhuis $E$ en $G$ vullen uit onder laminar air flow.

\title{
Bereiding van parenteralia in ziekenhuisapotheken
}

\section{Toetsing van de werkomstandigheden}

\author{
B.H. GRAATSMA ${ }^{1}$, F.A. BOOM ${ }^{2}$ EN E.TH.H.G.J. OREMUS ${ }^{3}$
}

\section{ABSTRACT}

Production of parenterals in hospital pharmacies

\section{Testing of production conditions}

During the production of large volume parenterals micro-organisms and particles have been counted with man, with the equipment and in the air of the production plant in seven Dutch hospital pharmacies.

As there is practically no correlation between the results and the differences in production conditions, further investigation, applying standardised in-process controls must be carried out.

To ensure optimal hygiene in the production plant, it is of highest importance to inform the staff on microbiological principles.

\section{SAMENVATTING}

In dit artikel worden enkele meetmethoden beschreven om bacterie- en deeltjestellingen uit te voeren bij de mens, de apparatuur en in de bereidingsruimten. Vervolgens worden de resultaten van deze tellingen, die zijn uitgevoerd in zeven Nederlandse ziekenhuisapotheken, besproken.

Gezien het vrijwel ontbreken van een correlatie tussen de resultaten van de tellingen en de verschillen in werkomstandigheden, is het ons inziens noodzakelijk dat volgens standaardmethoden aanvullend onderzoek wordt verricht.

Om een optimale persoonlijke en bedrijfshygiëne te handhaven, is het van groot belang dat de medewerkers in voldoende mate microbiologisch worden geschoold.

\footnotetext{
${ }^{1}$ Apotheek Academisch Ziekenhuis Dijkzigt, Dr. Molewaterplein 40, 3015 GD Rotterdam.

${ }^{2}$ Apotheek Slotervaartziekenhuis, Louwesweg 6, I 066 ec Amsterdam.

${ }^{3}$ Apotheek Academisch Ziekenhuis Groningen, Oostersingel 59, 9700 Rв Groningen. Correspondentie.
} 